\title{
Üniversite Kampüslerinde Öğrenci Yaşantısının Kalitesi: GTÜ Çayırova Kampüsü Örneği
}

\author{
Tayfun Salihoğlu1 ${ }^{*}$, Fatma Karasümen Açıkgöz ${ }^{2}$ \\ ${ }^{1}$ Gebze Teknik Üniversitesi, Mimarlık Fakültesi, Şehir ve Bölge Planlama Bölümü, Kocaeli. ${ }^{2}$ Osmaniye Korkut Ata Üniversitesi, Mimarlik, Tasarim ve \\ Güzel Sanatlar Fakültesi, Şehir ve Bölge Planlama Bölümü, Osmaniye. \\ ORCID: T. Salihoğlu (0000-0002-9959-6961), F. K. Açıkgöz (0000-0003-4778-1951)
}

\begin{abstract}
Özet
Yaşam kalitesi, bir toplumdaki yaşam koşullarını değerlendirmek için yaygın olarak kullanılan bir teorik çerçevedir. Bireyin ve toplumun herhangi bir konudaki ihtiyaçlarının karşılanma düzeyi olarak özetleyebileceğimiz memnuniyet düzeyi arttıkça, o toplumun yaşam kalitesinin de arttığı söylenebilmektedir. Kentsel mekâna yönelik ihtiyaçlar karşılandığında, mekândan duyulan memnuniyet yükselmekte ve bu durum kentsel yaşam kalitesi algısını olumlu yönde etkilemektedir. Bu bağlamda kentsel kullanım alanlarının birçoğuna kıyasla yüksek bir kullanıcı kitlesine hitap etmekte olan "üniversite kampüslerindeki yaşam kalitesi” konusu da kentsel yaşam kalitesi çalışmalarında ele alınabilecek konulardan biridir. Bu çalışmada Gebze Teknik Üniversitesi öğrencilerinin kampüs memnuniyetlerine etki eden faktörler belirlenmiş ve bu faktörlerin kampüs yaşam kalitesi algısı üzerindeki etkisinin tespit edilmesi amaçlanmıştır. Çalışma kampüs yaşam kalitesi gibi bir kentsel tasarım ölçeğindeki kullanıcı algısını analitik bir yaklaşımla açıklamaktadır. Gebze Teknik Üniversitesi'nde lisans öğrenimi görmekte olan ve tabakalı örneklem yöntemi ile seçilen 355 öğrenci ile kampüsten memnuniyeti ve kampüs yaşam kalitesi algısını ölçen bir anket çalışması yapılmıştır. Anket çalışmasına ilişkin yanıtlar, SPSS 20.0 programına aktarılmış olup, üniversite yaşam kalitesine ilişkin tanımlayıcı istatistikler, güvenilirlik analizi, faktör analizi, tek yönlü varyans (ANOVA) analizi ve regresyon analizi yapılmıştır. Analizler sonucunda kampüs memnuniyetinde üç faktörlü bir yapının var olduğu görülmüştür. Öğrencilerin akademik ve idari yönden duydukları memnuniyet yüksek, hizmetler yönünden duydukları memnuniyet orta, sosyal faaliyetler yönünden duyulan memnuniyet ise düşük düzeydedir. Öğrencilerin, akademik ve idari yönden, imkânlar ve hizmetler yönünden ve sosyal ve kültürel yönden memnuniyetleri arttıkça kampüs yaşam kalitesi algılarının da arttığı tespit edilmiştir.
\end{abstract}

Anahtar Kelimeler: Yaşam kalitesi; üniversitede yaşam kalitesi; öğrenci memnuniyeti

\section{GiRiș}

Geçmişten günümüze kadar yaşam kalitesi kavramı siyaset, ekonomi, psikoloji, sosyoloji, sağlık, eğitim gibi farklı disiplinlerde araştırılan bir konu olmuştur. Yapılan çalışmalarda toplumdaki yaşam koşullarını ölçmek ve elde edilen sonuçlar ışığında gerekli iyileștirme ve düzenlemeleri yapmak amaçlanmaktadır. Üniversite yaşam kalitesi çalışmaları da kentteki fonksiyonlardan biri olan ve küçük bir kent prototipi olarak kabul edebileceğimiz üniversite öğrencilerinin kampüsteki yaşantıdan duyduğu memnuniyet düzeyini ölçmek amacıyla yapılmaktadir.

Yaşam kalitesi araştırmalarında toplumu ilgilendiren birçok konu ele alınmaktadır. Bunlardan biri de toplumun yaşam kalitesini belirlemede büyük bir öneme sahip olan eğitimdir. Eğitim alanında da birçok araştır-

*Yazışma Adresi / Address for Correspondence:

T. Salihoğlu, Email: salihoglutayfun@gmail.com

Geliş Tarihi / Received Date: 00.00.2020

Kabul Tarihi / Accepted Date: 00.00.2020

Doi: $10.26701 /$ uad. 000000 macı, özellikle üniversite öğrencileri için yaşam kalitesi ölçümünü geliştirmiştir. Yaşam kalitesi, öğrencilerin yaşamlarıyla ilgili genel memnuniyetini ifade ederken, üniversite yaşam kalitesi ise öğrencilerin seçtikleri yükseköğretim kurumunda kendilerine sunulan hizmet, deneyim ve firsatlar ile ilgili memnuniyetlerini ifade etmektedir (Tho, 2019).

Öğrencilerin yaşam kalitesi, öğrencilerin genel yaşam doyumlarını, yani öğrencilerin aile hayatı, sosyal yaşamı, boş zamanları, finansal yaşamı, üniversite hayatı gibi yaşam alanlarından memnuniyet ve mutluluk durumlarını ifade etmektedir (Lee D.J., 2008).

Çalışmanın temelini oluşturan aşağıdan yukarıya yaşam memnuniyeti teorisinin temel önermesi; yaşam memnuniyetinin işlevsel olarak tüm yaşam alanları ve alt alanlarının memnuniyetiyle ilgili olduğudur. Yaşam doyumunun ise bu hiyerarşisinin tepesinde olduğu düşünülmektedir. Bu nedenle, yaşam doyumu, yaşam alanlarından memnuniyetten (örneğin, topluluktan, aileden, işten, sosyal hayattan, sağl1k vb.) etkilenmektedir. Diğer yandan; belirli bir yaşam al anı ile ilgili memnuniyet (örneğin, üniversite yaşamıyla ilgili memnuniyet), bu alan 


\title{
Quality of Student Life in University Campuses: Case of Gebze Technical University in Çayırova
}

\begin{abstract}
Quality of life is a widely used as the theoretical framework for assessing living conditions in a society. It can be said that as the level of satisfaction increases, which can be summarized as the level of meeting the needs of the individual and society in any subject, the quality of life of that society also increases. When the needs of people for urban space are met, the satisfaction with the place increases. This positively affects the perception of urban life quality. As the university campuses have higher number of users compared to many urban areas, the topic of "quality of life in university campuses" is one of the research motivations that can be addressed in quality of urban life studies. In this study, factors affecting the campus satisfaction and perception of quality of campus life of Gebze Technical University students were determined. The study explains an urban design issue with an analytical approach. The stratified sampling method was adopted in selecting 355 undergraduate students from Gebze Technical University who were subjected to questionnaire survey. The results from the survey were put onto SPSS 20.0 program where descriptive statistics, reliability analyses, factor analyses, one-way variance (ANOVA) analyses and regression analyses relating to university quality of life were run. As a result of the analysis, there is a three-factor structure in campus satisfaction. Students' academic and administrative satisfaction is high, their satisfaction with the services is moderate, and their satisfaction with social activities is low. As students' satisfaction on academic and administrative opportunities, services, and social and cultural aspects increase, their perception of quality of campus life also increases.
\end{abstract}

Keywords: Quality of life; university quality of life; student satisfaction

içindeki alt yaşam alanlarından (örneğin, üniversite yaşamının akademik yönleriyle ilgili memnuniyet) duyulan memnuniyetten etkilenmektedir (Sirgy, Grzeskowiak ve Rahtz, 2007). Üniversitedeki yaşantıdan memnuniyetin de üniversiteye devam etmekte olan öğrenciler için genel yaşam doyumu üzerinde önemli ve güçlü bir etkisi bulunmaktadır (Arslan ve Aktaş, 2014).

Yaşam kalitesi, öğrencilerin yaşamlarıyla ilgili genel memnuniyetini ifade ederken, üniversite yaşam kalitesi ise öğrencilerin seçtikleri yükseköğretim kurumunda kendilerine sunulan hizmet, deneyim ve firsatlar ile ilgili memnuniyetlerini ifade etmektedir. Bu kapsamda üniversitede öğrenim gören öğrencilerin memnuniyetlerinin araştırılması ve elde edilen bulgular ışı̆̆ında üniversitelerin geliştirilmesi ve sorunlara çözüm getirilmesi üniversitelerin gelişimi açısından önemi olduğu gibi, yaşam kalitesi gibi oldukça soyut bir kavramın zaman ve mekâna bağlı olarak değişken içeriğinin anlaşılması açısindan da önemsenmektedir (Tho, 2019; Neal, Uysal ve Sirgy, 2007).

Öğrencilerin kampüsteki yaşantının kalitesine ilişkin algilarının, cinsiyet (Cha, 2003; Dost, 2006) ekonomik durum (Cenkseven ve Akbaş, 2004; Mills, Grasmick, Morgan ve Wenk, 1992), eğitim (Astin, 1997; Sirgy vd., 2007), sosyal ortam (Çelik ve Akyol, 2015; Sirgy, 2012), kampüs tasarımı ve planlaması (Staeger-Wilson ve Sampson, 2012), planlama (Chang, Saha, Castro-Lacouture ve Yang, 2019; Razak, Abdullah, Nor, Usman ve Che-Ani, 2011), erişilebilirlik ve ulaşım (Matloob, Sulaiman, Ali, Shamsuddin ve Mardyya, 2014; Matloob 2016), kampüs güvenliği (Bahari ve Said, 2008; Lau ve Yang, 2009), rekreasyon (H.T. Fachrudin, K.A. Fachrudin ve Utami, 2019; Huesman 2007) ve temel ihtiyaçlara yönelik işlevlerin (İbili ve Uyanık, 2018) üniversite yaşam kalitesi bileşenleri ile ilişkili olduğu söylenebilmektedir. Üniversite ya- şam kalitesi bileşenleri Şekil 1'de ifade edilmektedir.

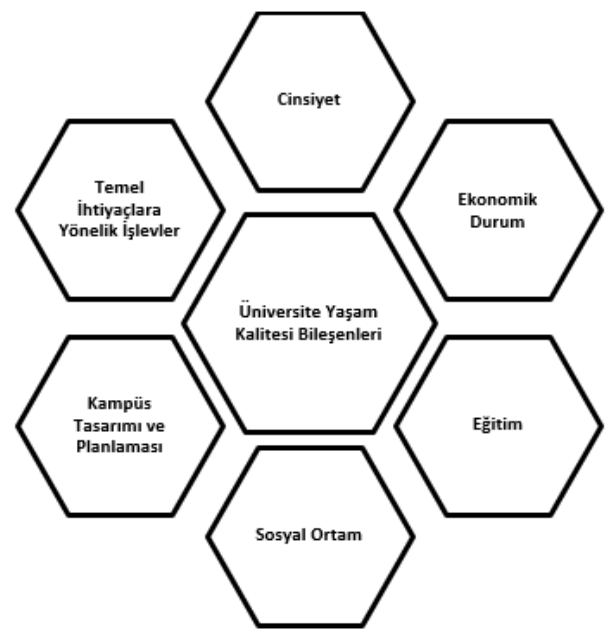

Şekil 1. Üniversite Yaşam Kalitesi Bileşenleri Kaynak: Açıkgöz ve Salihoğlu, 2020.

Arslan ve Akkaş'ın (2014) çalışmasında, üniversitenin genel yaşam kalitesi üzerinde, öğrencilerin kampüs olanaklarından duyduğu memnuniyetin en güçlü etkiye sahip olduğu görülmüştür. Wiers-Jenssen, Stensaker ve Gr gaard (2002), akademik yönden memnuniyet ile fiziksel ve sosyal iklimden duyulan memnuniyetin kampüste yer almaktan duyulan memnuniyet üzerinde olumlu etkiler gösterdiğini, boş zaman imkanlarının ise dolaylı olarak memnuniyet ile ilişkili olduğunu ortaya çıkarmışlardır. Y.J. Lee (2008) 'nin araştırmasında eğitim hizmetlerinden ve sosyal hizmetlerden memnuniyetin üniversitedeki yaşam kalitesi üzerinde anlamlı bir etkiye sahip olduğu, ancak idari hizmetlerden memnuniyetin yaşam kalitesini anlamlı bir şekilde etkilemediği tespit edilmiştir. Sirgy vd. (2007) ise üniversitenin akademik ve sosyal yönlerinden duyulan memnuniyetin üniversite yaşam kalitesi üzerinde anlamlı bir etkiye sahip olduğunu ortaya koymuşlardır. 
Gebze Teknik Üniversitesi kampüsü Kocaeli’nin Gebze ilçesinde Tuzla sınırında konumlanmaktadır. Gebze Teknik Üniversitesi (GTÜ) Türkiye'deki araştırma üniversitelerinden biri olmakla birlikte lisans alımlarında ve akademik başarıda üst sıralarda olan bir devlet üniversitedir. GTÜ akademik yönden hızlı bir gelişim göstermesine rağmen kampüs imkanlarının bu gelişime yeteri kadar ayak uyduramaması yönüyle Türk üniversitelerine ilişkin genel yargıyı desteklemektedir.

Bu çalışmanın amacı, Gebze Teknik Üniversitesi lisans öğrencilerinin kampüs kullanımının incelenmesi ve öğrencilerin akademik konular, kampüsteki temel hizmetler (genel kütüphane hizmetleri, sağlık hizmetleri, yeme-içme olanakları, güvenlik ve otopark hizmetleri) ile sosyal olanaklardan (eğlence ve dinlenme faaliyetleri, öğrenci kulüpleri, spor faaliyetleri) memnuniyetlerine bağlı olarak yaşam kalitesi algılarının geniş kapsamlı bir şekilde değerlendirilmesidir.

Bu amacı açıklamaya yönelik olarak, aşağıdaki alt sorulara yanıtlar aranmıştır:

- GTÜ, Çayırova Kampüsü’ndeki öğrenci yaşantısının kalitesine etki eden faktörler nelerdir?

- Öğrencilerin üniversitedeki yaşantının alt konularına ilişkin memnuniyetleri birbirinden anlamlı düzeyde farklılaşmakta mıdır?

- Öğrencilerin üniversitedeki yaşantının alt konularına ilişkin memnuniyeti ile kampüs yaşam kalitesinden memnuniyeti arasında bir ilişki var mıdır?

- Öğrencinin üniversitedeki genel memnuniyeti ile öğrenciye özgü koşullar (cinsiyet, öğrenim yılı, ikamet adresi, ikamet türü, ulaşım aracı, ulaşım süresi ve gelir) arasında bir ilişki var mıdır?

\section{ARAŞTIRMA YÖNTEMI}

Araştırma sorularının açıklanması için birincil veri kaynağı olarak, öğrencilerle yüz yüze görüşme yöntemiyle anket yapılmıştır. Anketin uygulanması için örneklem seçiminde tabakalı örneklem yöntemi uygulanmıştır. Anket görüşmeleri, 2019-2020 güz döneminde gerçekleştirilmiştir.

Çalışmada kullanılan ana kütle, üniversitedeki akademik bölümlerdeki öğrenci sayılarına göre tabakalandırılmıştır (Üstün, 2016). Çalışmada belirlenen sayıdaki örnekleme ulaşılıncaya kadar anket çalışması yapılarak örneklem oluşturulmuştur (Baltacı, 2018). Her bölümden kaç öğrenci seçileceği ise bölümlerdeki öğrenci sayıları ile oranlı olarak belirlenmiştir. Üniversitenin toplam öğrenci sayısı 4717 olup çalışmanın genellenebilirlik düzeyini sağlamak için gerekli örneklem sayısı \%95 güven aralığı ile 355 olarak hesaplanmış ve anket uygulaması yapılmiştır.

Anket çalışmasının ilk bölümünde öğrencilerin demografik özelliklerini içeren 12 adet soru sorulmuştur. Son- rasında beşli likert ölçeği (1: hiç memnun değilim - 5: çok memnunum) kullanılarak literatürde üniversite yaşantısının kalitesinden memnuniyeti yansıtan cinsiyet, ekonomik durum, eğitim, kampüs tasarımı ve planlaması, temel ihtiyaçlara yönelik işlevler ve sosyal ortam konuları ile ilgili olduğu kanıtlanmış 100 adet soru yöneltilmiştir (Napitupulu vd., 2018). Son olarak öğrencilere üniversitede bulunan bazı birimler hakkında kullanım sıklığı, yeterliliği gibi ifadelerin yer aldığı 39 adet soru sorulmuştur.

Hipotez testleri için, SPSS 20.0 programı kullanılarak üniversite yaşam kalitesine dair tanımlayıcı istatistiksel analizler, güvenilirlik analizi, faktör analizi, tek yönlü varyans (ANOVA) analizi ve regresyon analizi yapılmıştır (Kayaalp, Güney ve Cebeci, 2015).

\section{BULGULAR}

Araştırmanın amacına yönelik yapılan istatistiksel analizler verilmeden önce örneklem grubunun araştırma bünyesinde ölçek olarak kullanılan madde gruplarına verilen cevaplar sonucunda almış oldukları puanlara ilişkin ortalama, standart sapma, standart hata, minimum ve maksimum değerler hesaplanmıştır. Yapılan analizlerde "3"ün üzerinde olan sonuçlar öğrencilerin memnuniyetini, “3” ün altında olan sonuçlar öğrencilerin memnuniyetsizliğini ifade etmektedir.

\subsection{Genel Tanımlayıcılar}

Memnuniyete ilişkin sorulara verilen yanıtlara göre, akademik ve idari yönden memnuniyetin alt boyutlarında; en fazla memnun olunan konu, 3,64 ortalama ile öğretim üyelerinin ders hakkındaki bilgi birikiminden duyulan memnuniyet, en düşük ortalamaya sahip konu ise 2,52 ortalama ile derslerin zorluk seviyesidir.

İmkânlar ve hizmetler yönünden memnuniyet incelendiğinde ise öğrencilerin kampüste en fazla memnuniyet duydukları alanların 3,78 ortalama ile açık ve yeşil alanlar olduğu; buna karşın yurdun kampüsten uzakta konumlanmış olması, toplu taşıma konusunda karşılaşılan zorluklar ve öğrencilerin ulaşım maliyetinden dolayı maddi olarak sıkıntı yaşamaları sebebiyle yurt hizmetlerinden $(1,53)$ memnun olmadıkları görülmüştür.

Sosyal ve kültürel yönden memnuniyet boyutuna ilişkin olarak ise üniversite genelinde eğlenceye yönelik mekânların yetersiz olduğu, spor alanları, öğrenci kulüpleri ve kongre merkezleri ile toplantı salonlarının yeterliliklerinin diğer olanaklara göre daha yüksek olduğu tespit edilmiştir.

Çalışmada memnuniyete ilişkin alt konuların, öğrencilerin bireysel/demografik özelliklerinin alt kategorileri açısından farklılıkları tek yönlü varyans analizi (One Way ANOVA) ile test edilmiştir. Yapılan analizler sonucunda kütüphane hizmetlerinden memnuniyette kadınların erkeklere göre, 1. sınıftaki öğrencilerin 4. sınıfta olanlara göre daha memnun oldukları ortaya çıkmıştır. Sağlık 
hizmetlerinden duyulan memnuniyette ise, kadınların erkeklere göre, ailesiyle birlikte yaşayanların da yurtta kalanlara göre daha memnun oldukları tespit edilmiștir.

İdari personelden duyulan memnuniyette cinsiyete ve öğrenim yılına göre farklılıklar olduğu görülmüștür. İdari personelden, erkekler kadınlara göre, 4. sinıfta olanlar ise diğer sınıfta olanlara göre daha memnundur. Akademik personelden ise kadınların erkeklere göre ve 1. sınıf öğrencilerinin diğer sınıflara göre daha memnun oldukları görülmüştür. Yurt hizmetlerinden duyulan memnuniyette öğrenim yılı yönünden farklllıklar görülmüștür. İlk yılında olanların memnuniyetleri ailelerinden ilk defa ayrılıyor olmaları, sorumluluklarının artması ve koşullara alışamamış olmaları sebebiyle diğer sınıfta olanlara göre daha düşük çıkmıştır.

Son olarak genel memnuniyete bakıldığında 4.yılındaki öğrencilerin kampüs hayatına daha çok alışması ve üniversitenin imkânlarından daha fazla yararlanıyor olması sebebiyle kampüs memnuniyetleri yüksek çıkmıştır. Genel memnuniyet ikamet türüne göre de farklılaşmaktadır. Evde ailesiyle kalanların üniversiteden daha memnun oldukları görülmektedir. Son olarak özel araca sahip olanların okula daha konforlu șekilde gelmelerinden kaynaklı olarak bisiklet ile ulaşım sağlayan öğrencilere göre genel memnuniyetleri daha yüksektir.

\section{2. Üniversite Kampüslerindeki Çeşitli Konulardan Memnuniyete etki Eden Faktörler}

Çalışmada faktör analizi türlerinden en sık kullanılanı olan açıklayıcı faktör analizi kullanılmıştır. Sırasıyla akademik ve idari yönden memnuniyete ilişkin faktör analizi, imkân ve hizmetler yönünden memnuniyete ilișkin faktör analizi ve sosyal ve kültürel yönden memnuniyete ilişkin faktör analizi sonuçları aktarılmaktadır.Öğrencilerin akademik ve idari yönden memnuniyetine yönelik değişken sayısını azaltmak ve değişkenler arasındaki ilişkilerden yararlanarak bazı yeni yapılar ortaya çıkarmak amacıyla 21 adet ifadeye verdikleri cevaplar ile faktör analizi yapılmıștır (Tablo 1). Faktör yük değeri maddelerin alt boyutlarla olan ilişkisini açıklayan bir katsayıdır. Bu araştırmada alt kesme noktası olarak 0.40 kabul edilmiştir. Faktörlerin belirlenmesi aşamasının ardından hangi maddelerin hangi faktörler altında kümelendiğini bulabilmek için tüm maddelere Varimax rotasyonu uygulanmıştır.

Analiz sonucunda dört bileșenden ve 21 maddeden oluşan akademik ve idari yönden memnuniyet son halini almakta olup; personelden memnuniyet, ders içeriğinden memnuniyet, derslikten memnuniyet ve iletişim hizmetlerinden memnuniyet olmak üzere 4 faktöre ayrılmıștır. 4. faktörün toplam varyansı açıklama yüzdesi $\% 62,826$ olduğu sonucuna varılmıștır (Tablo 2).
Tablo 1. Akademik ve İdari Yönden Memnuniyete İlişkin Faktör Yükleri

\begin{tabular}{|c|c|c|c|c|c|}
\hline \multirow{2}{*}{$\begin{array}{l}\text { Faktör } \\
\text { İsimleri }\end{array}$} & \multirow{2}{*}{ Memnuniyete Yönelik Anket Soruları } & \multicolumn{4}{|c|}{ Bileşenler } \\
\hline & & 1 & 2 & 3 & 4 \\
\hline \multirow{7}{*}{ 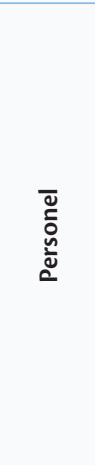 } & $\begin{array}{l}\text { Öğretim üyelerinin ders hakkındaki bilgi } \\
\text { birikiminden }\end{array}$ & 842 & & & \\
\hline & $\begin{array}{l}\text { Öğretim üyelerinin ders anlatma ve } \\
\text { iletişim becerilerinden }\end{array}$ & 812 & & & \\
\hline & Öğretim üyesi-öğrenci ilişkisinden & 787 & & & \\
\hline & Öğretim üyelerine erişim kolaylığından & ,769 & & & \\
\hline & $\begin{array}{l}\text { İdari personelin talep ve görüşleri işleme } \\
\text { koyma biçiminden }\end{array}$ & ,685 & & & \\
\hline & $\begin{array}{l}\text { Idari personelin genel hizmet kalite- } \\
\text { sinden }\end{array}$ & ,684 & & & \\
\hline & $\begin{array}{l}\text { Öğretim üyelerinin teknolojik imkânları } \\
\text { kullanımından }\end{array}$ & & 641 & & \\
\hline \multirow{5}{*}{ 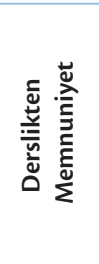 } & Sınıfların ders öğrenme imkanından & & 813 & & \\
\hline & $\begin{array}{l}\text { Sınıf büyüklüğünün öğrenci sayısı ile } \\
\text { orantılı olmasından }\end{array}$ & & 797 & & \\
\hline & Masa ve sandalyelerin yeterliliğinden & & ,777 & & \\
\hline & Sınıfların aydınlatma, Isı ve akustiğinden & & ,724 & & \\
\hline & Sinıftaki teknolojik altyapılardan & & 678 & & \\
\hline \multirow{5}{*}{ } & Derslerin içeriğinden & & & ,768 & \\
\hline & Derslerin zorluk seviyesinden & & & ,736 & \\
\hline & Genel ders yükümden/saatlerimden & & & ,732 & \\
\hline & Sınavların ölçme düzeyinden & & & 688 & \\
\hline & Öğrenme kaynaklarının yeterliliğinden & & & ,634 & \\
\hline \multirow{4}{*}{ 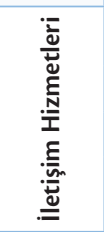 } & Kablosuz ağın kullanılabilirliğinden & & & & 845 \\
\hline & Kablosuz ağa erişim hızından & & & & 822 \\
\hline & Bilgisayar laboratuvarlarından & & & & 666 \\
\hline & $\begin{array}{l}\text { Ihtiyaç duyduğumda açık bilgisayarların } \\
\text { varlığından }\end{array}$ & & & & 642 \\
\hline
\end{tabular}

$K M O=0,87$, Cronbach's Alpha $=0,931 p<0,005$

Tablo 2. Akademik ve İdari Yönden Memnuniyet Için Açıklanan Toplam Varyans (Total Variance Explained for Academic and Administrative Satisfaction)

\begin{tabular}{|c|c|c|c|}
\hline Faktörler & Toplam & Varyans Yüzdesi & Kümülatif Yüzdesi \\
\hline Personel & 4,289 & 20,425 & 20,425 \\
\hline Derslikler & 3,276 & 15,602 & 36,027 \\
\hline Ders içerikleri & 2,897 & 13,794 & 49,821 \\
\hline iletişim Altyapısı & 2,731 & 13,005 & 62,826 \\
\hline
\end{tabular}

İmkânlar ve hizmetler yönünden memnuniyete ilişkin 28 adet ifadeye de faktör analizi yapılmış ve faktör yükleri ortaya koyulmuştur (Tablo 3).

İmkânlar ve hizmetler yönünden memnuniyete ilişkin yapılan faktör analizi ile Tablo 4'te belirtildiği üzere yeme-içme olanaklarından memnuniyet, kütüphaneden memnuniyet, erişilebilirlikten memnuniyet, öğrenci yurdundan memnuniyet ve sağlık hizmetlerinden duyulan memnuniyet olmak üzere 7 faktöre ayrılmıștır. 7 faktörün toplam varyansı açıllama yüzdesi $\% 68,777$ olduğu sonucuna varılmıștır.

Sosyal ve kültürel etkinlikler yönünden memnuniyete ilişkin 17 adet ifade yapılan faktör analizi spor olanaklarından memnuniyet, kültürel olanaklardan memnuniyet ve eğlence ve rekreasyon alanlarının kullanımından 
memnuniyet olmak üzere 3 faktöre indirgenmiștir. 3 faktörün toplam varyansı açıklama yüzdesi \%68,440 olduğu sonucuna varılmıştır (Tablo 5 ve 6).

Tablo 3. İmkân ve Hizmetler Yönünden Memnuniyete lişskin Faktör Yükleri

\begin{tabular}{|c|c|c|c|c|c|c|c|c|}
\hline \multirow{2}{*}{ 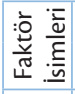 } & \multirow{2}{*}{$\begin{array}{l}\text { Memnuniyete Yönelik Anket } \\
\text { Soruları }\end{array}$} & \multicolumn{7}{|c|}{ Bileşenler } \\
\hline & & 1 & 2 & 3 & 4 & 5 & 6 & 7 \\
\hline \multirow{5}{*}{ 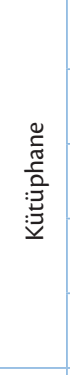 } & $\begin{array}{l}\text { Genel kütüphane hizmetle- } \\
\text { rinden }\end{array}$ & ,785 & & & & & & \\
\hline & $\begin{array}{l}\text { Kütüphanede aradığım kaynak- } \\
\text { ların bulunabilirliğinden }\end{array}$ & ,787 & & & & & & \\
\hline & $\begin{array}{l}\text { Ödünç alma-verme sürele- } \\
\text { rinden }\end{array}$ & ,772 & & & & & & \\
\hline & $\begin{array}{l}\text { Kütüphanedeki çalışma } \\
\text { ortamları }\end{array}$ & ,670 & & & & & & \\
\hline & $\begin{array}{l}\text { Kütüphane personelinin öğren- } \\
\text { ciye yaklaşımından }\end{array}$ & ,652 & & & & & & \\
\hline \multirow{5}{*}{$\frac{E}{\sum_{\bar{w}}^{\frac{E}{4}}}$} & $\begin{array}{l}\text { Kampüsteki araç yollarının nitelikli } \\
\text { ve yeterli olmasından }\end{array}$ & & 778 & & & & & \\
\hline & Otopark alanlarından & & ,739 & & & & & \\
\hline & $\begin{array}{l}\text { Bisiklet yolları ve bisiklet park } \\
\text { alanlarından }\end{array}$ & & ,696 & & & & & \\
\hline & $\begin{array}{l}\text { Kampüs içerisinde yaya olarak } \\
\text { dolaşım kolaylığından }\end{array}$ & & ,687 & & & & & \\
\hline & $\begin{array}{l}\text { Kampüs içinde kantine erişi- } \\
\text { mimden }\end{array}$ & & ,631 & & & & & \\
\hline \multirow{5}{*}{ 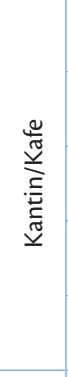 } & $\begin{array}{l}\text { Kafenin mekânsal yeterliliğin- } \\
\text { den }\end{array}$ & & & 799 & & & & \\
\hline & $\begin{array}{l}\text { Kafedeki yiyeceklerin fiyatla- } \\
\text { rından }\end{array}$ & & & ,771 & & & & \\
\hline & $\begin{array}{l}\text { Kantindeki yiyeceklerin fiyat- } \\
\text { larından }\end{array}$ & & & ,671 & & & & \\
\hline & $\begin{array}{l}\text { Kafedeki ürünlerin kalitesi ve } \\
\text { çeşitliliğinden }\end{array}$ & & & ,654 & & & & \\
\hline & $\begin{array}{l}\text { Kantinin mekânsal yeterlili- } \\
\text { ğinden }\end{array}$ & & &, 516 & & & & \\
\hline \multirow{3}{*}{ 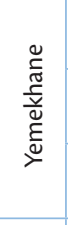 } & $\begin{array}{l}\text { Yemekhanedeki yiyeceklerin } \\
\text { kalitesi ve çeşitliliğinden }\end{array}$ & & & & 843 & & & \\
\hline & $\begin{array}{l}\text { Yemekhanenin temizlik ve } \\
\text { bakımından }\end{array}$ & & & & ,729 & & & \\
\hline & $\begin{array}{l}\text { Yemekhanenin mekânsal yeter- } \\
\text { liliğinden }\end{array}$ & & & & ,693 & & & \\
\hline \multirow{3}{*}{ 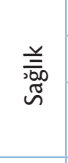 } & Sağlık hizmetlerine erişimimden & & & & & 649 & & \\
\hline & Genel sağlık hizmetlerinden & & & & & 868 & & \\
\hline & $\begin{array}{l}\text { Sağlık personelinden (doktor,- } \\
\text { hemşire,idari personel) }\end{array}$ & & & & & 859 & & \\
\hline \multirow{2}{*}{$\stackrel{+}{\ni}$} & $\begin{array}{l}\text { Öğrenci yurdunun kampüse } \\
\text { olan mesafesinden }\end{array}$ & & & & & & 920 & \\
\hline & $\begin{array}{l}\text { Öğrenci yurduna ulaşım imkan- } \\
\text { larından }\end{array}$ & & & & & & ,893 & \\
\hline \multirow{2}{*}{ 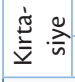 } & Kırtasiyenin hizmetinden & & & & & & & 630 \\
\hline & Kırtasiyenin fiyatlarından & & & & & & & ,781 \\
\hline
\end{tabular}

Tablo 4. İmkân ve Hizmetler Yönünden Memnuniyet İçin Açıklanan Toplam Varyans

\begin{tabular}{|c|c|c|c|}
\hline Faktörler & Toplam & Varyans Yüzdesi & Kümülatif Yüzdesi \\
\hline Kütüphane Hizmeti & 3,341 & 12,849 & 12,849 \\
\hline Erişim & 3,165 & 12,174 & 25,024 \\
\hline Kantin/ Kafe Olanakları & 3,151 & 12,121 & 37,145 \\
\hline Yemekhane Olanakları & 2,531 & 9,736 & 46,880 \\
\hline Sağlık Hizmetleri & 2,276 & 8,752 & 55,633 \\
\hline Yurtlar & 1,849 & 7,111 & 62,744 \\
\hline Kırtasiye Hizmeti & 1,569 & 6,033 & 68,777 \\
\hline
\end{tabular}

Tablo 5. Sosyal ve Kültürel Yönden Memnuniyet Faktörlerine Yüklenen Sorular

\begin{tabular}{|c|c|c|c|c|}
\hline \multirow{2}{*}{ 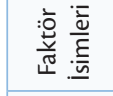 } & \multirow{2}{*}{ Anket Soruları } & \multicolumn{3}{|c|}{ Bileşenlerin Değeri } \\
\hline & & 1 & 2 & 3 \\
\hline \multirow{8}{*}{$\begin{array}{l}\frac{\pi}{\pi} \\
\frac{\pi}{\pi} \\
\frac{\pi}{\pi} \\
\frac{1}{0} \\
0\end{array}$} & Spor alanlarının kullanım saatlerinden & 931 & & \\
\hline & Spor alanlarındaki alet ve ekipmanlardan & 908 & & \\
\hline & Spor alanları temizlik ve bakımından & 889 & & \\
\hline & Spor alanlarının yönetiminden & 879 & & \\
\hline & Spor alanlarının çeşitliliğinden & 818 & & \\
\hline & Spor alanlarının ücretlerinden & 812 & & \\
\hline & $\begin{array}{l}\text { Spor faaliyetleri ile ilgili yapılan bilgilendir- } \\
\text { melerden }\end{array}$ & ,779 & & \\
\hline & Spor alanlarının yeterliliğinden & ,763 & & \\
\hline \multirow{4}{*}{ 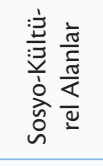 } & Kulüplerin aktivitelerinden & & ,771 & \\
\hline & Öğrenci Kulüplerinin çeşitliliğinden & & 693 & \\
\hline & Akademik etkinliklerden & & ,656 & \\
\hline & Konferans ve seminer etkinliklerinden & &, 552 & \\
\hline \multirow{4}{*}{ 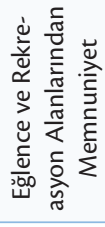 } & Sergi ve konser aktivitelerinden & & & ,745 \\
\hline & Kampüsteki eğlence alanlarından & & &, 716 \\
\hline & $\begin{array}{l}\text { Kampüsteki rekreasyon alanlarının kullanı- } \\
\text { mı ve yeterliliğinden }\end{array}$ & & &, 563 \\
\hline & $\begin{array}{l}\text { Dinlenme alanlarından (kafe, okuma salonu } \\
\qquad \mathrm{vb} \text {.) }\end{array}$ & & & ,445 \\
\hline
\end{tabular}

$\mathrm{KMO}=0,931$, Cronbach's Alpha $=0,906 \mathrm{p}<0,005$

Kampüs yaşam kalitesi ile çok sayıda parametreden oluşan yapının, üç alt konudaki faktör analizleri (Şekil 2) ile yukarıdaki faktörlere indirgenmesinin ardından, bu faktörlerin araştırmanın ana konusunu oluşturan kampüs yaşam kalitesiyle ilişkisi çoklu doğrusal regresyon analizi ile incelenmiştir.

Tablo 6. Sosyal ve Kültürel Yönden Memnuniyet İçin Açıklanan Toplam Varyans

\begin{tabular}{|c|c|c|c|}
\hline Faktörler & Toplam & $\begin{array}{c}\text { Varyans } \\
\text { Yüzdesi }\end{array}$ & $\begin{array}{c}\text { Kümülatif } \\
\text { Yüzdesi }\end{array}$ \\
\hline Spor Alanları & 5,209 & 32,558 & 32,558 \\
\hline Sosyo-Kültürel Alanlar & 3,071 & 19,194 & 51,752 \\
\hline $\begin{array}{c}\text { Eğlence ve Rekreasyon Alanların- } \\
\text { dan Memnuniyet }\end{array}$ & 2,670 & 16,688 & 68,440 \\
\hline
\end{tabular}

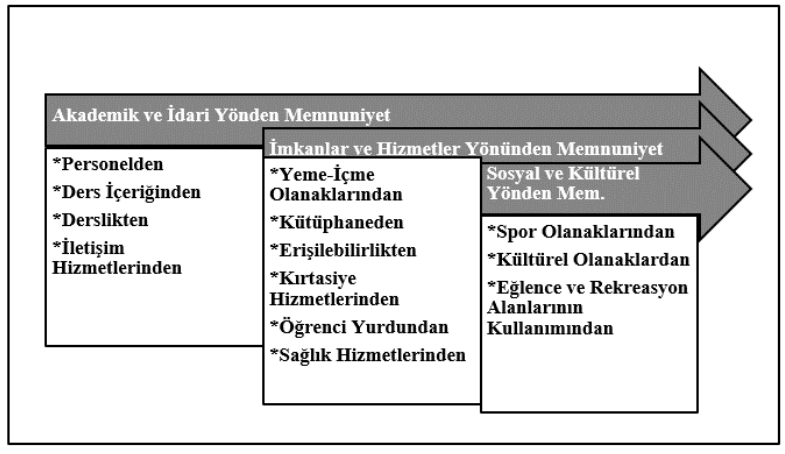

Şekil 2. Kampüs Yaşam Kalitesine Ait Faktörler

\subsection{Kampüs Yaşam Kalitesinden Memnuniyet Regresyon Modeli}

"Kampüs Yaşam Kalitesinden Memnuniyet Regresyon Modeli" olarak adlandırdığımız bu modelin bağımlı değişkeni, ankette yer verilen, “Tüm Bu Konuları Göz 
Önünde Bulundurarak GTÜ, Çayırova Kampüsünde Öğrenci Olarak Yer Almaktan Ne Kadar Memnunsunuz?" sorusuna verilen yanıtlardır. Bağımsız değişkenler ise yukarıda ifade edilen; Personel, Ders İçeriği, Derslikler, İletişim Altyapısı, Erişim, Kantin/ Kafe Hizmetleri, Yemekhane, Sağlık Hizmetleri, Yurtlar, Kırtasiye Hizmetleri, Spor Alanları, Sosyo-Kültürel Alanlar, Eğlence ve Rekreasyon Alanları olarak indirgenen faktörlerin hesaplanan skorlarıdır.

Analiz sonucunda üç faktörün kampüs yaşam kalitesinden memnuniyet ile anlamlı bir ilişki içerisinde olduğu ortaya çıkmıştır. Bunlar; derslerin içeriği, spor alanları ve sosyo-kültürel alanlardır (Tablo 7).

Değişkenlerin genel memnuniyeti hangi oranda etkilediğini ölçen Beta katsayısına göre; sosyo-kültürel alanlardan duyulan memnuniyet, 0,382 değeri ile genel memnuniyeti en çok etkileyen konudur. Sosyo-kültürel alanlara ilişkin faktörleri oluşturan konular arasında kampüsteki eğlence alanları, dinlenme alanları ve spor alanlarının ücretleri konularında öğrencilerin yüksek memnuniyetsizliğe sahip oldukları, ders içeriğinden memnuniyet faktörlerinde ise ders içeriğinden ve öğrenme kaynaklarının yeterliliğinden duyulan memnuniyetin en yüksek olduğu görülmüştür. Kampüsteki temel altyapılar olan imkân ve hizmetler yönünden memnuniyet boyutuna ilişkin yeme-içme olanaklarından, kütüphaneden, erişilebilirlikten, kırtasiye hizmetlerinden, yurt hizmetlerinden ve sağlık hizmetlerinden duyulan memnuniyetin yaşam kalitesi üzerinde anlamlı bir etkisinin olmadığı ortaya çıkmıștır. Regresyon belirleme katsayısının 0.17 gibi bir düzeyde olduğu görülmekle birlikte, çalışmanın bir tahmin çalışması olmadığı, sosyal bilimler alanında kavramlar arasındaki ilişkileri araştıran bir yapıda kurgulandığı göz önünde bulundurulduğunda regresyon belirleme katsayısının düzeyinin bu araştırma için bir sorun teşkil etmediği söylenebilir.

\section{SONUÇLAR VE ÖNERILER}

Gebze Teknik Üniversitesi'nde yapılan bu çalışma öğrencilerin üniversite ile ilgili hem genel hem de alt boyutlara ilişkin memnuniyet seviyelerini ölçmesi ve genel memnuniyete etki eden faktörlerin incelenmesi bakımından önem taşımaktadır.

Cinsiyet açısından bakıldığında öğrencilerin memnuniyetinde kadınların sağlık hizmetlerinden, kütüphane hizmetlerinden ve akademik personelden daha memnun oldukları, erkelerin ise spor hizmetlerinden daha memnun oldukları ortaya çıkmıştır. Genel memnuniyet açısından bakıldığında ise cinsiyetler arasında anlamlı bir farklılık bulunamamıştır. Cinsiyetin memnuniyet üzerine etkisi üzerine yapılmış literatür çalışmalarında, Dost (2006) cinsiyet farklılı̆̆ bakımından memnuniyette anlamlı bir fark bulamamıșken; Astin (1997) erkeklerin daha kararlı olduğunu; Low (2000), Özben (2013) ve Ren (2009) ise çalıșmalarında kadınların erkeklerden daha yüksek memnuniyete sahip olduklarını belirtmișlerdir. $\mathrm{Bu}$ sonuçlara göre cinsiyetin memnuniyet üzerinde etkisinin farkllılık gösterdiği görülmektedir. Cenksever ve Akbaş (2004), Chow (2005) ve İlhan, Batmaz ve Akhan (2010)'ın araştırmalarında ekonomik durumun öğrencinin memnuniyeti üzerinde etkisi olduğunu, iyi yaşam koşullarına ve gelir seviyesine sahip öğrencilerin daha memnun oldukları ortaya koymuşlardır. Buna karşın, bu araştırmada, öğrencilerin aylık kazançlarının memnuniyetlerine etki etmediği görülmüştür.

GTÜ, Çayırova Kampüsü Yaşam Kalitesi Araştırmasında, hizmetler yönünden memnuniyette; en fazla yeme-içme olanakları ve sağlık hizmetleri, sonrasında kütüphane hizmetleri, kırtasiye fiyatları ve yurda ulaşım imkânları genel memnuniyet üzerinde pozitif yönde anlamlı bir etkiye sahiptir. Çalışmamızı destekler nitelikteki Aldemir ve Gülcan (2004), araştırmasında sağlık hizmetlerinin genel memnuniyetle ilişkili olduğunu, Wiers-Jenssen vd. (2002) destek hizmetleri altında bulunan kütüphane, kafe gibi hizmetlerin genel memnuniyet üzerinde olumlu etkiler gösterdiğini, Clemes, Gan ve Kao (2008) hizmet kalitesinin iyileștirilmesinin öğrencinin memnuniyet düzeyinin arttırdığını belirtmişlerdir.

Kampüsteki çeşitli konulara ilişkin memnuniyetlere yönelik incelemede, öğrencilerin en çok akademik ve idari yönden memnuniyet duydukları görülmüştür. İmkânlar ve hizmetler yönünden duyulan memnuniyet orta düzeyde, spor ve kültürel faaliyetler yönünden memnuniyetleri ise düşük düzeyde çıkmıștır. Öğrenciler akademik personel ile ilgili öğretim üyelerinin ders hakkındaki bilgi birikiminden, öğretim üyelerine erişim kolaylığından, öğretim üyelerinin ders anlatma ve iletişim becerilerinden ve sınıftaki öğretim üyesi-öğrenci ilişkisinden oldukça memnuniyet duymaktadırlar. Bu da üniversitedeki akademik eğitimin öğrenciyi tatmin ettiğini göstermektedir. Buna karşın yurdun üniversite kampüsünden uzak mesafede konumlanmış olması sebebiyle öğrenciler üniversitenin yurt olanaklarından memnuniyet duymamaktadırlar. Aynı zamanda öğrencilerin yeme-içme hizmetlerinden, kırtasiye hizmetlerinden ve sosyal ve kültürel faaliyetlerden de memnuniyet duymadıkları ortaya konulmuştur. Ortaya çıkan bu sonuçları destekleyen çalışmalara bakıldığında; Aldemir ve Gülcan (2004), Arslan ve Akkaş (2013) ve Çitil (2006) üniversitede eğitim veren öğretim üyelerinin gerekli bilgiye ve ilgiye sahip olmasının, ders konusunda yüksek performans göstermelerinin öğrenci memnuniyeti üzerinde etkisi olduğu sonucuna ulaşmışlardır. Yine bu konuda Clemes vd. (2008), D.J. Lee (2008), Sirgy vd. (2007) ve Wiers-Jenssen vd. (2002) akademik yönden duyulan memnuniyetin üniversite yaşam kalitesi üzerinde anlamlı bir etkiye sahip olduğunu belirtmişlerdir. Tüm bunlardan farklı olarak Aldemir ve Gülcan (2004) ve D.J. Lee (2008)'nin çalışmalarında idari personelden memnuniyetin genel memnuniyete etkisinin olmadığı görülmüştür. 
Tablo 7. Genel Memnuniyet için Çoklu Doğrusal Regresyon Analizi Sonuçları

\begin{tabular}{|c|c|c|c|c|c|c|c|}
\hline \multirow[b]{2}{*}{ MODEL 3} & \multicolumn{2}{|c|}{$\begin{array}{l}\text { Std. Olmayan } \\
\text { Katsayılar }\end{array}$} & \multirow{2}{*}{$\begin{array}{c}\text { Standardize Katsayılar } \\
\text { Beta }\end{array}$} & \multirow[b]{2}{*}{$l$} & \multirow[b]{2}{*}{$\mathrm{p}$} & \multicolumn{2}{|c|}{ Collinearity İstatistikleri } \\
\hline & B & Std. Hata & & & & Tolerans & VIF \\
\hline SABIT & 2,876 & 088 & & 32,638 & & & \\
\hline Sosyo-Kültürel Alanlar & ,382 & 085 & ,330 & 4,472 & ,000 & 994 & 1,006 \\
\hline Spor Alanları & ,295 & 092 & ,235 & 3,193 & ,002 & 999 & 1,001 \\
\hline Derslerin İçeriği & ,190 & 084 & 167 & 2,264 & 025 & 994 & 1,006 \\
\hline
\end{tabular}

Durbin - Watson: 1,964; VIF <10, Tolerance >0,2; Condition Index <100; Cook's Distance <1; Artık Histogramları: Normal Dağılıma Uygun, QQ Plot: Doğru Üzerinde.

Yapılan faktör analizi sonucunda akademik ve idari yönden memnuniyet 4 alt faktöre, imkânlar ve hizmetler yönünden memnuniyet 7 alt faktöre ve sosyal ve kültürel yönden memnuniyet 3 alt faktöre ayrılmıştır. Çoklu doğrusal regresyon analizine göre öğrencilerin genel üniversite yaşam memnuniyetlerini sosyo-kültürel alanların, spor alanlarının ve ders içeriğinin etkilediği sonucuna varılmıştır. Sosyal ve kültürel yönden üniversite yaşam kalitesini etkileyen faktörlere bakıldığında bu çalışmada spor alanlarının, konferans ve seminer aktivitelerinin ve dinlenme alanlarının genel memnuniyet üzerinde etkisi olduğunu görmekteyiz. Spor ve rekreasyon alanları ise spor ve kültürel yönden genel memnuniyet üzerinde en fazla etkiye sahip olan konular olarak öne çıkmaktadır. Bu makalede ortaya konulan sonuca paralel olarak Arslan ve Akkaş (2013), Çitil vd. (2006), Wiers-Jenssen vd. (2002), Sirgy vd. (2007) sosyal yönlerden duyulan memnuniyetin üniversite yaşam kalitesi üzerinde anlamlı bir etkiye sahip olduğunu, Tinto (1990), Huesman (2009) ve Zizzi (2004), öğrencilerin üniversitenin sosyal ve akademik hayatına yüksek düzeyde entegrasyonunun öğrencinin üniversiteye olan bağlılığını arttırdığını ortaya koymuşlardır.

Çalışmadaki açı uçlu sorularda, üniversitede karşıllaşılan sorunlara ilişkin açı uçlu çözüm önerileri de iletilmiştir. Üniversite yönetiminin öğrencilerin yurt sorununa ilişkin, üniversiteye yakın bir konumda, daha erişilebilir bir yurdu öğrencilerin hizmetine sunmaları öğrencilerin üniversiteye yönelik memnuniyetsizliklerini büyük oranda azaltacaktır. Bununla birlikte yeme-içme konusunda duyulan memnuniyetsizlikler göz önüne alındığında kampüs içinde yeme-içme konusunda hizmet veren işletme sayısı arttırılmalı ya da ücretler makul seviyeye çekilmelidir. Kampüs içerisinde öğrencilerin boş zamanlarını geçirebilecekleri, dinlenip sosyalleșebilecekleri mekânların bulunmaması ve kampüs çevresinde sosyal imkânların yetersizliğinden dolayı üniversite yönetiminin öğrencilere kampüs içinde yeterli sosyal ve kültürel faaliyetleri sağlamaları öğrencilerin üniversiteye olan bağlılıklarının ve memnuniyetlerinin artması konusunda oldukça faydalı olacaktır. Kampüsün doğal güzelliğini bozmadan öğrencilerin dinlenebilecekleri, kitap okuyup, ders çalışabilecekleri uygun rekreasyon alanları tasarlanması, öğrencilerin okulda daha fazla vakit geçirmelerine olanak sağlayacaktır. Mevcutta var olan bisiklet dağıtımı hizmetinin genişletilmesi ve bisiklet yollarının iyileștirilmesi ile öğrenciler kampüs içi ulaşımda daha konforlu hareket etme imkânına sahip olacaklardır.

Bu çalışma, bir kentsel tasarım alanı olan üniversitelerdeki yaşam kalitesini öğrenci memnuniyeti bakış açısıyla analitik bir yaklaşımla ölçmesi ve sonuçlarını tasarım alanıyla ilişkilendirmesi bakımından kentsel planlama ve tasarım alanına, istatistik biliminin temel hipotez testlerini planlama alanında uygulamasıyla da istatistik alanına özgün bir katkı sağlamaktadır.

Diğer yandan; çalışma çeşitli sınırlamalara da sahiptir. İlk olarak tek seferlik bir çalışma olduğundan ötürü öğrencilerin fikirlerinde zaman içerisindeki değişimi yakalayamamaktadır. İkinci olarak ise, yaşam kalitesini etkileyen bileşenler ayrı ayrı değerlendirilmekte olup birbirlerini etkileyen değişkenlerin genel etkileri ölçülmemektedir.

\section{KAYNAKÇA}

Abd-Razak, M., Utaberta N., and Handryant A.N. (2012). A study of students' perception on sustainability of campus design: A case study of four research universities campus in Malaysia. Research Journal of Environmental and Earth Sciences, 4(6): p. 646-657.

Açıkgöz, F.K. ve Salihoğlu, T. (2020). “Üniversite Kampüslerinde Öğrenci Yaşantısının Kalitesi: Gebze Teknik Üniversitesi Örneği” Yüksek Lisans Tezi, Gebze Teknik Üniversitesi, Fen Bilimleri Enstitüsü, Gebze.

Aldemir, C. and Gülcan Y. (2004). Student satisfaction in higher education. Higher education management and policy, 16(2): p. 109-122. https://doi.org/10.1787/17269822.

Arslan, S., ve Akkas, O. A.. (2014). Quality of college life (QCL) of students in Turkey: Students' life satisfaction and identification. Social Indicators Research, 115(2), 869-884. https:// doi.org/10.1007/s11205-013-0235-9.

Astin, A.W. (1997). What matters in college? Four critical years revisited. San Francisco: Jossey-Bass.

Bahari, N.B. ve Said, I.B. (2008). A Greenway Network for University Campus. Faculty of Built Environment, Universiti Teknologi Malaysia, Skudai, Johor, Malaysia.

Baltacı, A. (2018). Nitel araştırmalarda örnekleme yöntemleri ve örnek hacmi sorunsalı üzerine kavramsal bir inceleme. Bitlis Eren Üniversitesi Sosyal Bilimler Enstitüsü Dergisi, 7(1): p. 231-274.

Cenkseven, F. ve Akbaş, T. (2004). Üniversite ögrencilerinde öznel ve psikolojik iyi olmanin yordayicilarinin incelenmesi. Yayimlanmamis doktora tezi, Çukurova Üniversitesi, Sosyal Bilimler Enstitüsü, Adana.

Cha, K. H. (2003). Subjective well-being among college students. Social Indicators Research. 62(1-3): p. 455-477, https://doi. org/10.1023/A:1022669906470. 
Chang, S., Saha, N., Castro-Lacouture, D., Yang, P. (2019). Multivariate relationships between campus design parameters and energy performance using reinforcement learning and parametric modeling. Applied Energy, 249: p. 253-264. https://doi.org/10.1016/j.apenergy.2019.04.109.

Chow, H.P. (2005). Life satisfaction among university students in a Canadian prairie city: A multivariate analysis. Social indicators research, 70(2): p. 139-150. https://doi.org/10.1007/ s11205-004-7526-0.

Clemes, M.D., Gan, C.E. ve Kao, T.H. (2008). University student satisfaction: An empirical analysis. Journal of Marketing for Higher Education, 17(2): p. 292-325. https://doi. org/10.1080/08841240801912831.

Çelik, A.K. ve Akyol, K. (2015). Predicting Student Satisfaction with an Emphasis on Campus Recreational Sports and Cultural Facilities in a Turkish University. International Education Studies, 8(4): p. 7-22.

Çitil, M., İspir, E., Söğüt, Ö. ve Büyükkasap, E. (2006). Fen edebiyat fakültesi öğrencilerinin profilleri ve başarılarını etkilediğine inandıkları faktörler; KS Ü. örneği. Erzincan Eğitim Fakültesi Dergisi, 8(2): p. 69-81.

Dost, M.T. (2006). Subjective well-being among university students. Hacettepe Üniversitesi Eğitim Fakültesi Dergisi, 31(31): p. 188-197.

Fachrudin, H.T., Fachrudin, K.A. ve Utami, W. (2019). Education Activities to Realize Green Campus. Asian Social Science, 15(8).

Huesman, R., Brown, A., Lee, G., Kellogg, J., ve Radcliffe, P. (2007). Modeling student academic success: Does usage of campus recreation facilities make a difference? Paper presented at the National Symposium of Student Retention, Milwaukee.

İbili, E. and Uyanık, H. (2018). Öğrencilerin Yurt Memnuniyet Düzeyleri ile Kişisel Gelişim Yönelimleri Arasındaki İlişkinin İncelenmesi. Yükseköğretim Dergisi,. 8(3): p. 293-300.

Illhan, N., Batmaz, M. ve Akhan, L.U. (2010). Üniversite öğrencilerinin sağlıklı yaşam biçimi davranışları. Maltepe Üniversitesi Hemşirelik Bilim ve Sanatı Dergisi, 3(3): p. 34-44.

Kayaalp, G.T., Güney, M.Ç. ve Cebeci, Z. (2015). Çoklu Doğrusal Regresyon Modelinde Değişken Seçiminin Zootekniye Uygulanışı. Çukurova Üniversitesi Ziraat Fakültesi Dergisi, 30(1): p. 1-8.

Lau, S. ve Yang, F. (2009). Introducing Healing Gardens into a Compact University Campus: Design Natural Space to Create Healthy and Sustainable Campuses. Landscape Research, 34(1): p. 55-81. DOI: 10.1080/01426390801981720.

Lee, D. J. (2008). A model of quality of college life (QCL) of students in Korea. Social Indicators Research, 87(2), 269-285. https://doi.org/10.1007/s11205-007-9172-9.

Lee, Y. J. (2008). Subjective quality of life measurement in Taipei. Building and Environment, 43(7), 1205-1215. https://doi.org/10.1016/j.buildenv.2006.11.023.

Low, L. (2000). Are College Students Satisfied? A National Analysis of Changing Expectations. New Agenda Series [TM].

Matloob, F.A., Sulaiman, A. B., Ali, T.H., Shamsuddin, S. ve Mardyya, W.D. (2014). Sustaining campuses through physical character-the role of landscape. Procedia-Social and Behavioral Sciences, 140: p. 282-290. https://doi.or- g/10.1016/j.sbspro.2014.04.421.

Matloob, F.A. 2016. Sustainable Campus Desgin in Baghdad University, Iraq. Universiti Teknologi Malaysia.

Mills, R.J., Grasmick, H.G., Morgan, C.S. ve Wenk, D. (1992). The effects of gender, family satisfaction, and economic strain on psychological well-being. Family Relations, p. 440-445. DOI: $10.2307 / 585588$.

Napitupulu, D., Rahim, R., Abdullah, D., Setiawan, M.I., Abdillah, L.A., Ahmar, A.S., Simarmata, J., Hidayat, R., Nurdiyanto, H. ve Pranolo, A. (2018). Analysis of student satisfaction toward quality of service facility. in Journal of Physics: Conference Series. IOP Publishing. DOI: 10.1088/1742-6596/954/1/012019.

Neal, J.D., Uysal, M. ve Sirgy, M.J. (2007). The effect of tourism services on travelers' quality of life. Journal of travel research, 46(2): p. 154-163. https://doi. org/10.1177/0047287507303977.

Ozben, S. (2013). Social skills, life satisfaction, and loneliness in Turkish university students. Social Behavior and Personality: an international journal, 41(2): p. 203-213. https://doi. org/10.2224/sbp.2013.41.2.203.

Razak, M.Z.A., Abdullah, N.A.G., Nor, M.F.I.M., Usman, I.M.S. ve Che-Ani, A.I. (2011).Toward a sustainable campus: comparison of the physical development planning of research university campuses in Malaysia. Journal of Sustainable Development, 4(4): p. 210. doi: 10.5539/jsd.v4n4p210.

Ren, W. (2009). A research on the subject well-being of regional college students. International Journal of Psychological Studies, 1(1): p. 51-53. https://doi.org/10.18826/useeabd.598909.

Sirgy, M.J. (2012). The psychology of quality of life: Hedonic well-being, life satisfaction, and eudaimonia. Vol. 50. Springer Science \& Business Media.

Sirgy, M. J., Grzeskowiak, S. ve Rahtz, D. (2007). Quality of college life $(\mathrm{QCL})$ of students: Developing and validating a measure of well-being. Social Indicators Research, 80(2), 343-360. https://doi.org/10.1007/s11205-005-5921-9.

Staeger-Wilson, K. ve Sampson, D.H. (2012). Infusing JUST Design in Campus Recreation. Journal of Postsecondary Education and Disability, 25(3): p. 247-252.

Tho, N. D. (2019). Business students' hardiness and its role in quality of university life, quality of life, and learning performance. Education+ Training, 61(3), 374-386. https://doi. org/10.1108/ET-03-2018-0068 .

Tinto, V. (1990). Principles of effective retention. Journal of The First-Year Experience \& Students in Transition, 2(1): p. 3548.

Üstün, B. (2016). Örnekleme Yöntemleri. Retrieved from https:// www.phdernegi.org/wp-content/uploads/2016/03/\%C3\%BGrnekleme_yontemleri.pdf.

Wiers-Jenssen, J., Stensaker, B. r., ve Gr gaard, J. B. (2002). Student satisfaction: Towards an empirical deconstruction of the concept. Quality in higher education, 8(2), 183-195. https://doi.org/10.1080/1353832022000004377.

Zizzi, S., Ayers, S.F., Watson II, J.C. ve Keeler, L. (2004). Assessing the impact of new student campus recreation centers. NASPA Journal, 41(4): p. 588-630. DOI: 10.2202/00276014.1390 